International Journal of Current Advanced Research

ISSN: O: 2319-6475, ISSN: P: 2319 - 6505, Impact Factor: SJIF: 5.995

Available Online at www.journalijcar.org

Volume 6; Issue 4; April 2017; Page No. 3177-3179

DOI: http://dx.doi.org/10.24327/ijcar.2017.3179.0217

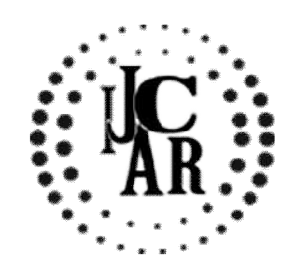

Research Article

\title{
AWARENESS ON BENEFICIAL EFFECTS OF MILLETS BASED DIET AMONG SOUTH INDIAN POPULATION
}

\section{Saranya.M*}

Saveetha Dental College and Hospitals-600 077

\begin{tabular}{|c|c|}
\hline A $R$ T T I C L E $\quad$ I N F O & A B S T R A C T \\
\hline $\begin{array}{l}\text { Article History: } \\
\text { Received } 8^{\text {th }} \text { January, } 2017 \\
\text { Received in revised form } 27^{\text {th }} \text { February, } 2017 \\
\text { Accepted } 22^{\text {nd }} \text { March, } 2017 \\
\text { Published online } 28^{\text {th }} \text { April, } 2017 \\
\text { Key words: } \\
\text { Millets Based Diet, } \\
\text { South Indian Population }\end{array}$ & $\begin{array}{l}\text { Aim: To do a survey on awareness on beneficial effects on millets based diet. } \\
\text { Objective: Millet are host of nutrients in human body. They are easily digestible. } \\
\text { They have serotonin which help in calming mood swings. } \\
\text { Background: Millet is an important drought-resistant crop and the 6th cereal crop in the } \\
\text { world in terms of agriculture production. Also, millet has resistance to pests and diseases, } \\
\text { short growing season, and productivity under drought conditions when compared to major } \\
\text { cereals. Therefore, millet grains are now receiving specific attention in terms of utilization } \\
\text { as food from developing countries as well asfrom some developed countries in terms of its } \\
\text { good potential in the manufacturing of bioethanol and biofilms from some developed } \\
\text { countries in terms of its good potential in the manufacturing of bioethanol and biofilms. } \\
\text { Reasons: In South Indian population, Rice is the staple food. People who consume millet } \\
\text { are very less.Since the nutritional value of millets are higher than that of rice, decided to } \\
\text { create an awareness on the beneficial effects of millets. }\end{array}$ \\
\hline
\end{tabular}

Copyright $\mathrm{C} 2017$ Saranya.M. This is an open access article distributed under the Creative Commons Attribution License, which permits unrestricted use, distribution, and reproduction in any medium, provided the original work is properly cited.

\section{INTRODUCTION}

The most important parameter of food is the nutritional quality of food for maintaining human health and complete physical well being. Since nutritional well being is the driving force for development and maximisation of human genetic potential ${ }^{[1]}$. Dietary quality of food should be taken into consideration for maintaining human health and fitness for solving the problem of malnutrition ${ }^{[2]}$. Some of the agricultural foods are not used as human main food because of unawareness of people. Millet are one of them. They are generally used as animal and bird feed. ${ }^{[3]}$ Millets are not utilised properly and are neglected crop because of little knowledge to people and some critical problems like lower cooking quality, taste and low bioavailability of millets. ${ }^{[1]}$

Millets are small grains which are primarily produced in India. These can be seen as highly variable small seeded grasses which is grown as cereal. They are grown in semiarid parts of Asia and Africa. ${ }^{[4]}$ These are grown in warm climate.In developingcountries $97 \%$ of millet is produced. ${ }^{[4]}$ Millets are given less importance in developing countries. There are seven types of millets they are pearl millet (Kambu), finger millet (Ragi), foxtail millet (Thinai), Kodo millet (Varagu), barnyard millet (Kuthiravali), little millet (Saamai) and Sorghum (Cholam) $)^{[3]}$. Potassium, calcium and iron are in high contents in millets.

*Corresponding author: Saranya.M

Saveetha Dental College and Hospitals-600 077
In terms of magnesium and zinc content it is second to barley and it is also secondary when it comes to rye in terms of antioxidant capacity. Millet contains significant level of chromium. Pearl millet is also known asPennisetumglaucum (botanical name). They are grown in India and Africa. It is gluten free cereal crop. They are small, round and golden yellow in colour. It is also known as common millet. Among common millet varieties, the best source of proteins is from pearl millet. It contains an average of about $14.5 \%$ of protein. Finger millet is also known as African finger millet. It is very much popular in SouthernIndia. Calcium and protein is rich in finger millet.Cardiovascular disease can be prevented by finger millet by reducing plasma triglycerides in hyperlipidemic rats ${ }^{[5]}$. It contains Essential Amino Acids (EAA) which is essential for our body. Foxtail millet is pest free millet. Iron content is very much high in these millets. Green gram are delicate pulses which are stored by fumigants, but act as anti pest agents. Blood sugar and cholesterol levels and increase HDL cholesterol are controlled by them. Kodo millets are rich in fibre and low on fat. Polyphenols, an antioxidant compound are in high content in kodo millet. They are good for diabetes. Little millet are high in iron content and antioxidant activity. They are very smaller in size when compared to other millet. Little millet helps in diabetes and diseases related to stomach. Barnyard millet helps in curing type 2 diabetes and cardiovascular disease. They are rich in fibre, phosphorous and calcium. They have low glycemic index. 
Sorghum are mostly grown in fodder value. It is one of the ancient cereal grain.Unsaturated fats, proteins, fibre and minerals like phosphorous, potassium, calcium and iron are in high content in sorghum. It helps to improve metabolism. Millets can control and prevent various health diseases which affects our health. They are:- Magnesium present in millet helps to lower blood pressure, decreases the chances of strokes and heart attacks. Millet helps to balance cholesterol level ${ }^{[7]}$.Intake of millets regularly can prevent women from getting onset of breast cancer and type 2 diabetes. Millet helps in detoxifying the body. It can also prevent asthma and wheezing among young children. It helps in reducing chronic diseases such as obesity, diabetes and cancer ${ }^{[9]}$. Anti nutrients such as phenolic acids, tannins and phytate are rich in millets. It reduces the risk for colon and breast cancer. ${ }^{[6]}$ Aldose reductase is an inhibitor which prevents the accumulation of sorbitol and reduces the risk of diabetes induced cataract diseases. ${ }^{[8]}$

\section{MATERIALS AND METHOD}

The survey was done through an online way. With 100 responses among the South Indian population from the age of 18 and above. They were required to fill the questionnairewhich included 19 questions related to the beneficial effects of millets. Then finally, the respective responses were verified and the analysis was prepared from the results obtained by making suitable pie charts for better understanding and information.

\section{RESULTS AND DISCUSSION}

The statistically analysed data are represented below:- These pie charts represents how much the participants are conscious about benefits of millet which helps in curing these health problems. From these pie charts it is proved that still the people are not conscious about the benefits of millets.

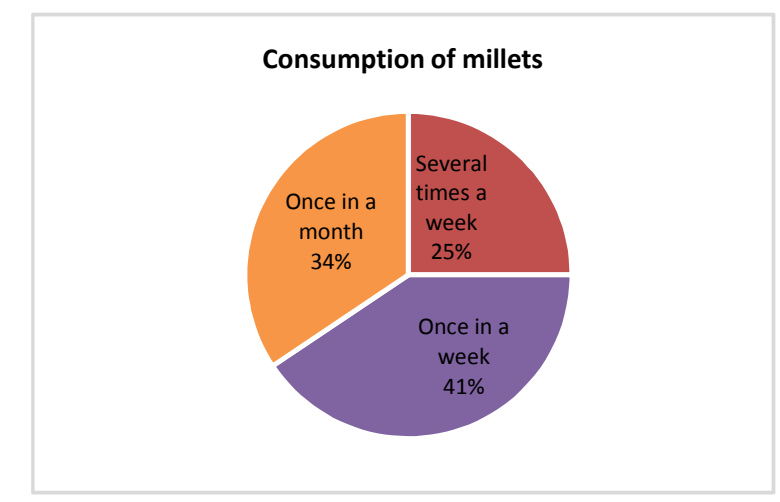

Lowers risk of type 2 diabetes



\section{Prevents onset of breast cancer}

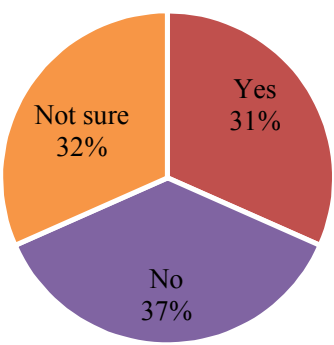

Vitamin B3 in millet can help lower cholesterol

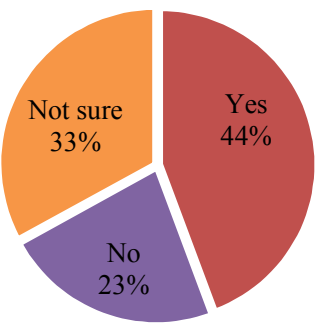

Reduce risk of wheezing and asthma among young children



\section{Magnesium in millet can help reduce} the affect of heart attack

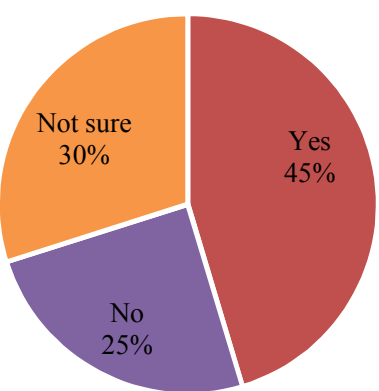

According to my survey, $25 \%$ of people consume millets several times in a week, $41 \%$ of people consume millets once in a week and $34 \%$ of people consume millets once in a month. $50 \%$ of people are aware that millet lowers risk of type 2 diabetes, $30 \%$ are not aware that millet lowers risk of 
type 2 diabetes and $20 \%$ of people are not sure about it. $31 \%$ are aware millet can prevent onset of Breast cancer, $37 \%$ are not aware about prevention of breast cancer and $32 \%$ are not aware about it. 44\% are aware Vitamin B3 in millet can help lower cholesterol, $23 \%$ are not aware about vitamin B3 can help lower cholesterol and $33 \%$ are not sure about it. $41 \%$ are aware millet can reduce risk of wheezing and asthma among young children, $28 \%$ are not aware and $31 \%$ are not sure about it. $45 \%$ are aware $\mathrm{Mg}$ in millet can help reduce heart attack, $25 \%$ are not aware about $\mathrm{Mg}$ in millet can help reduce heart attack and $30 \%$ are not sure about it.

\section{CONCLUSION}

Millet is a staple food. It contains lots of fibres. Due to occurrence of malnutrition indeveloping countries, various health problemslike obesity, diabetes, cardiovascular disease, breast cancer is occurred. It is the most prominent because of inadequate supply of nutrition. This is mainly due to the unawareness and lack of knowledge of the people.

\section{References}

1. Sarita- Department of Food Science \& Nutrition, Faculty of Home Science, Banasthali University, Tonk, Rajasthan-304022, India and Ekta Singh -Associate Professor; Department of Food Science \& Nutrition, Faculty of Home Science, Banasthali University, 304022, India Tonk, Rajasthan- 304022, India. Potential of millets: Nutrients composition and health benefits. Journal of scientific and innovative research 2016; 5(2): 46-50

2. Singh P \&Raghuvanshi RS. Finger Millet for Food and Nutrition Security. African Journal of Food Science. 2012; 6(4): 77-84.
3. YangX, WanZ, PerryL, LuH, WangQ, HaoC, LiJ, XieF, YuJ, CuiT, Wang T, Li M \& Ge QH. Early Millet Use in Northern China. Proc. Nat. Acad. Sci. 2012; USA. pp. 1-5.

4. McDonough, Cassandrea M, Rooney Lloyd W, SernaSaldivar Sergio O. "The Millets". Food Science and Technology: Handbook of Cereal Science and Technology (CRC Press). 2000; 99 2nd ed. 177-210.

5. Lee SH, Chung I-M, Cha Y-S \& Parka Y. Millet Consumption Decreased Serum Concentration of Triglyceride and C-Reactive Protein But Not Oxidative Status in Hyperlipidemic Rats. Nutr. Res. 2010; 30: 290-296.

6. Chandrasekara A \&Shahidi F. Antiproliferative Potential and DNA Scission Inhibitory Activity of Phenolics from Whole Millet Grains. J. Funct. Foods. 2011c; 3: 159-170.

7. Coulibaly A, Kouakou B \& Chen J. Phytic Acid in Cereal Grains: Structure, Healthy or Harmful Ways to Reduce Phytic Acid in Cereal Grains and their Effects on Nutritional Quality. Am. J. Plant Nutr. Fert. Technol. 2011; 1: 1-22.

8. Chethan S, Dharmesh SM \&Malleshi NG. Inhibition of Aldose Reductase from Cataracted Eye Lenses by Finger Millet (Eleusine Coracana) Polyphenols. Bioorg. Med. Chem. 2008a; 16: 10085-10090.

9. Rao BR, Nagasampige MH \&Ravikiran M. Evaluation of Nutraceutical Properties of Selected Millets. J. Pharma. BioalliedSci. 2011; 3(2): 277- 279.

\section{How to cite this article:}

Saranya.M (2017) ' Awareness On Beneficial Effects Of Millets Based Diet Among South Indian Population', International Journal of Current Advanced Research, 06(04), pp. 3177-3179.

DOI: http://dx.doi.org/10.24327/ijcar.2017.3179.0217 